\title{
Effects of feeding grass or red clover silage cut at two maturity stages in dairy cows. 2. Dry matter intake and cell wall digestion kinetics
}

\author{
K. Kuoppala, ${ }^{11}$ S. Ahvenjärvi, ${ }^{*}$ M. Rinne, ${ }^{*}$ and A. Vanhatalo† \\ ${ }^{*}$ MTT Agrifood Research Finland, Animal Production Research, FI-31600 Jokioinen, Finland \\ †University of Helsinki, Department of Animal Science, PO Box 28, FI-00014 University of Helsinki, Finland
}

\begin{abstract}
This study examined the effects of red clover or grass silages cut at 2 stages of growth on feed intake, cell wall digestion, and ruminal passage kinetics in lactating dairy cows. Five dairy cows equipped with rumen cannulas were used in a study designed as a $5 \times 5$ Latin square with 21-d periods. Diets consisted of early-cut and late-cut grass and red clover silages and a mixture of late-cut grass and early-cut red clover silages offered ad libitum. All diets were supplemented with $9 \mathrm{~kg} / \mathrm{d}$ of concentrate. Ruminal digestion and passage kinetics were assessed by the rumen evacuation technique. Apparent total-tract digestibility was determined by total fecal collection. The silage dry matter intake was highest when the mixed forage diet was fed and lowest with the early-cut red clover diet. Delaying the harvest tended to decrease DMI of grass and increase that of red clover. The intake of neutral detergent fiber (NDF) and potentially digestible NDF (pdNDF) was lower but the intake of indigestible NDF (iNDF) was higher for red clover diets than for grass diets. The rumen pool size of iNDF and the ratio of iNDF to pdNDF in the rumen contents were larger, and pool sizes of NDF and pdNDF were smaller for red clover than for grass silage diets. Outflow of iNDF and the ratio of iNDF to pdNDF in digesta entering the omasal canal were larger, and the outflow of pdNDF was smaller for red clover than for grass silage diets. The digestion rate $\left(k_{d}\right)$ of pdNDF was faster for red clover diets than for grass silage diets. Delaying the harvest decreased $\mathrm{k}_{\mathrm{d}}$ for grass but increased it for red clover silage diets. Observed differences in fiber characteristics of red clover and grass silages were reflected in ruminal digestion and passage kinetics of these forages. The low intake of early-cut red clover silage could not be explained by silage digestibility, fermentation quality, or rumen fill, but was most likely related to nutritionally suboptimal composition because inclusion of moderate quality grass silage im-
\end{abstract}

Received March 27, 2009

Accepted July 9, 2009.

${ }^{1}$ Corresponding author: kaisa.kuoppala@mtt.fi proved silage intake. Increasing the maturity of ensiled red clover does not seem to affect silage dry matter intake as consistently as that of grasses.

Key words: red clover silage, grass silage, cow, fiber digestion

\section{INTRODUCTION}

Red clover (Trifolium pratense) is the most important forage legume in northern Europe and is also commonly used in the United States and Canada. The rising costs of $\mathrm{N}$ fertilizers have recently increased the interest in utilizing legumes in dairy production because of their unique ability to bind atmospheric N.

Red clover, like other forage legumes, is known for greater intake potential and animal performance than grasses (Dewhurst et al., 2003). Huhtanen et al. (2007) reported, based on a meta-analysis of 53 diets, that replacing grass with legumes increased silage DMI in a curvilinear manner so that the maximum intake was reached when legumes comprised 0.80 of silage DM. However, the relative silage DMI index was unable to predict accurately the intake responses to replacement of grass with a high $(>0.5)$ proportion of legumes (Huhtanen et al., 2007). These findings suggest that some of the factors regulating the intake of these forages may be unknown.

Digestibility is one of the most important factors affecting forage intake (Huhtanen et al., 2007). The cell soluble matter is almost totally digested by the ruminant animal, so the amount and quality of cell wall (i.e., NDF) determines the total digestibility of forage (Van Soest, 1994). The cell wall concentration and digestibility change during the development and growth of the plant (Rinne and Nykänen, 2000; Kuoppala et al., 2008). The effects of growth stage on the digestibility and DMI of grass silages have been well documented (Huhtanen et al., 2007) but studies focusing on the maturity effects of red clover silage in dairy cows are scarce.

Legumes differ from grass species both in terms of chemical composition and feeding value characteristics (Van Soest, 1994). Red clover usually contains more 
protein, ash, and lignin and less NDF than grasses of corresponding digestibility (Weisbjerg and Søegaard, 2008). Differences in morphology and cellular structures between grasses and legumes affect rumen functions and digestion (Wilson and Kennedy, 1996).

Intake and digestibility depend on the rate of NDF digestion in the rumen, on the rate of breakdown of feed particles, and on the rate of digesta outflow from the rumen (Mertens, 1993). The decrease of feed digestibility clearly affects the rumen functions: the outflow rate increases and the pool sizes of DM, NDF, and indigestible NDF (iNDF) increase when the digestibility of grass silage decreases (Rinne et al., 2002). Compared with those in grasses, the rates of breakdown in the rumen and outflow from the rumen are higher in forage legumes (Wilson and Kennedy, 1996). Despite the higher content of totally indigestible lignin, legumes are digested at a higher rate compared with grasses (Smith et al., 1972).

Most of the research with forage legumes has been conducted with alfalfa or white clover, which differ from red clover with respect to intake and digestion properties (Dewhurst et al., 2003). Finnish experiments have used mainly mixed grass and red clover silages where the proportion of red clover has changed from 15 to $75 \%$ (Heikkilä et al., 1992, 1996). In the present study, red clover silages were made from pure cultures at 2 stages of growth to elucidate factors contributing to the observed higher DM intakes of cows fed red clover-containing silage. The hypothesis was that the faster digestion and passage kinetics of the cell wall of red clover would account for the higher intake. To evaluate this hypothesis, the effects of red clover and grass silages cut at 2 growth stages on feed intake, digestion, and passage kinetics were studied in lactating dairy cows. Because most of the red clover is grown as mixed swards with grasses in practice, the fifth dietary treatment was designed to consist of a 1:1 mixture of late-cut grass silage and early-cut red clover silage. Data on N metabolism, AA supply, and milk production are presented in the companion paper (Vanhatalo et al., 2009).

\section{MATERIALS AND METHODS}

\section{Herbages and Silages}

Four silages were made from primary growth: 2 grass silages from mixed timothy (Phleum pratense)-meadow fescue (Festuca pratensis) sward and 2 red clover (Trifolium pratense) silages, during the growing season of 2003 in Jokioinen, Finland $\left(60^{\circ} 49^{\prime} \mathrm{N}, 23^{\circ} 28^{\prime} \mathrm{E}\right)$. A detailed description of the preparation of silages and conduct of the experiment is given in the companion paper (Vanhatalo et al., 2009). In brief, both silages were harvested at an early and late growth stage; June 17 and 26, respectively, for grass, and July 2 and 16, respectively, for red clover. The timing of the harvests was intended to produce a 5-percentage-unit difference in the concentration of digestible OM in DM (D-value) of silages between the early and late cuts of the plant species. The sward was cut with a mower conditioner, wilted for approximately 3 to $7 \mathrm{~h}$, and harvested with a precision-chop harvester. Herbage was preserved with a formic-acid based additive (AIV2Plus, Kemira GrowHow Ltd., Helsinki, Finland) applied at a rate of 5 $\mathrm{L} / \mathrm{t}$ for grass and $6 \mathrm{~L} / \mathrm{t}$ for red clover silages in bunker silos (grass) or clamps (red clover).

For botanical and morphological analysis, samples of the stands were collected from the same fields within an area of $20 \times 5 \mathrm{~m}$ adjacent to the silage harvest areas. Samples were collected with $0.5-\times 0.5-\mathrm{m}$ frames taking at least 4 subsamples with a cutting height of 5 $\mathrm{cm}$. Morphological analysis was conducted by manually dissecting the plants into leaves, stems, and inflorescences. Proportions of red clover, timothy, and meadow fescue, other plant species (weeds), and dead tissue in the sample DM were determined.

\section{Cows, Diets, and Experimental Design}

Two grass and 2 red clover silages and a mixture of late-cut grass and early-cut red clover silages (1:1 on DM basis, mixed thoroughly before feeding with a rotating mixer of $150 \mathrm{~L}$ volume) were fed ad libitum with $9 \mathrm{~kg} / \mathrm{d}$ of concentrate to 5 dairy cows fitted with rumen cannulas (10 cm i.d., Bar Diamond Inc., Parma, ID). The study consisted of 5 diets offered to each animal according to a $5 \times 5$ Latin square design. Cows averaged 77 (SD 28.5) DIM and $620 \mathrm{~kg}$ (SD 71.3) of BW at the beginning of the experiment. Each experimental period lasted $21 \mathrm{~d}$, consisting of a 12-d adaptation period and a 9-d sample collection period. Cows had free access to silage during adaptation periods, but during sample collection periods, intake was restricted to 0.95 of that recorded on the second week of each period. Intake restriction was used to minimize variations between and within days in diet intake during sampling.

The concentrate supplement comprised (\% of air DM) barley (40.5), oats (40.0), rapeseed expeller (16.0), and minerals (3.5). Because of the higher content of $\mathrm{Ca}$ in red clover silages, the basic concentrate mixture was formulated to be as low as possible with no mineral Ca added. The Ca intake between diets was balanced by daily inclusion of extra $\mathrm{Ca}$ supplements for the grass silage and mixed forage diets. Chemical and mineral compositions of concentrates are reported in detail in the companion paper (Vanhatalo et al., 2009). 
Cows were kept in tie stalls and had continuous access to water. Concentrates and silages were offered 4 times daily at 0600, 0900, 1800, and $2000 \mathrm{~h}$, respectively. Cows were milked at 0700 and $1700 \mathrm{~h}$. Milk production and composition are reported in the companion paper (Vanhatalo et al., 2009). All experimental procedures were approved by the local animal care and use committee.

\section{Measurements and Analytical Methods}

Samples of the harvested herbage were collected during silage making from every load (approximately $2 \mathrm{~kg}$ of fresh weight per load) inserted into the silos. Representative samples of fresh silages and concentrates were collected daily during the sample collection period. Herbage and feed samples were stored at $-20^{\circ} \mathrm{C}$ and thawed, mixed, and submitted for chemical analysis at the end of the experiment. Fresh silage samples were analyzed for $\mathrm{pH}$, DM, ash, VFA, water-soluble carbohydrates (WSC), ammonia N, and soluble N. The methods of analysis were reported in more detail in Kuoppala et al. (2008).

Concentration of NDF was determined by heating samples sealed in nylon bags (F57, Ankom Technology, Fairport, NY) in an Ankom 220 Fiber Analyzer using detergent solutions prepared according to Van Soest et al. (1991) with sodium sulfite in the NDF-detergent solution and $\alpha$-amylase for samples containing starch. The concentration of NDF is presented on an ash-free basis. Permanganate-lignin was determined according to Robertson and Van Soest (1981).

To determine rumen pool sizes of DM, OM, CP, NDF, iNDF, and potentially digestible NDF (pdNDF), rumen evacuations were conducted on d 13 (before morning feeding) and $\mathrm{d} 15$ (6 h after morning feeding). The times were chosen to represent times of minimum and maximum rumen fill. Rumen contents were emptied manually through the cannula, kept warm in a water bath, mixed thoroughly, weighed, and sampled (2-3 $\mathrm{kg}$ ). After sampling, the total digesta were returned to the rumen as soon as possible. Total-tract digestibility of nutrients was measured by total fecal collection on $\mathrm{d}$ 18 to 21 of each period.

To assess ruminal $\mathrm{pH}$ and $\mathrm{NH}_{3}$ concentration, liquid samples of 100 to $150 \mathrm{~mL}$ were obtained on d 14 before the morning meal and 1.5, 3, 4.5, 6, 7.5, 9, and $10.5 \mathrm{~h}$ thereafter via rumen cannula using a perforated plastic tube. Digesta flow entering the omasal canal was assessed by the triple marker method using 2 external markers: Cr-EDTA and Yb-acetate as markers for liquid phase and small particle phase, respectively, and an internal marker, iNDF, as marker for large particle phase. The details of the rumen fluid and digesta determinations are reported in the companion paper (Vanhatalo et al., 2009).

Indigestible NDF of feeds, feces, and large-particle and small-particle phases of omasal canal digesta were determined by 12-d ruminal incubation (in duplicates) in dairy cows fed forage-rich diets and using nylon bags with a pore size of $17 \mu \mathrm{m}$ (Huhtanen et al., 1994) and expressed on an ash-free basis. Potentially digestible NDF was calculated as the difference between NDF and iNDF.

Apparent in vivo digestibility of the 4 silages was measured with sheep by total fecal collection. The digestibility trial was conducted according to a Latin square design with 21 -d periods, the last $7 \mathrm{~d}$ being used for fecal collection. Silages were offered at approximately maintenance level ( $35 \mathrm{~g}$ of DM per $\mathrm{kg}$ of $\mathrm{BW}^{0.75}$ ) and supplemented daily with $30 \mathrm{~g}$ of mineral mixture and $10 \mathrm{~g}$ of $\mathrm{NaCl}$. Sheep were fed twice daily and had free access to drinking water.

\section{Calculations and Statistical Analysis}

Ash-free neutral detergent solubles (NDS) were calculated as the difference between OM and NDF. Rumen pool sizes were calculated as the mean of the 2 evacuation times and represent the average rumen fill. Parameters of digestion kinetics were calculated as follows:

$$
\begin{gathered}
\text { Rate of intake }\left(\mathbf{k}_{\mathbf{i}}\right)=1 / 24 \times(\text { intake, } \mathrm{kg} / \mathrm{d}) / \\
(\text { rumen pool size, } \mathrm{kg}) ; \\
\text { Rate of passage }\left(\mathbf{k}_{\mathbf{p}}\right)=1 / 24 \times(\text { omasal canal } \\
\text { flow, } \mathrm{kg} / \mathrm{d}) /(\text { rumen pool size, } \mathrm{kg}) ; \\
\text { Rate of digestion }\left(\mathbf{k}_{\mathrm{d}}\right)=\mathrm{k}_{\mathrm{i}}-\mathrm{k}_{\mathrm{p}} .
\end{gathered}
$$

Data were analyzed using ANOVA for a Latin square design with the following model:

$$
\mathrm{Y}_{\mathrm{ijk}}=\mu+\mathrm{A}_{\mathrm{i}}+\mathrm{P}_{\mathrm{j}}+\mathrm{D}_{\mathrm{k}}+\mathrm{e}_{\mathrm{ijk}},
$$

where $Y_{\mathrm{ijk}}$ is the dependent variable, $\mu$ is the overall mean, $A_{i}$ is the fixed cow effect, $P_{j}$ is the period effect, $D_{k}$ is the diet effect, and $e_{i j k}$ is the residual effect. Sums of squares of the diet effects were further divided into the following comparisons: grass silage versus red clover silage; early versus late growth stage; interaction between plant species effect and growth stage effect; pure culture diets of late grass and early red clover versus mixed forage diet. Least squares means and statistical significances $(P \leq 0.1)$ are presented in the tables. The 
Table 1. Effects of dietary forage source and stage of maturity on morphological and chemical composition of herbages

\begin{tabular}{lrrrrr}
\hline & \multicolumn{2}{c}{ Grass } & & \multicolumn{2}{c}{ Red clover } \\
\cline { 2 - 3 } \cline { 5 - 6 } Item & Early & Late & & Early & Late \\
\hline DM, \% & 24.0 & 23.9 & & 15.9 & 16.7 \\
Morphological composition, \% of DM & & & & & \\
$\quad$ Leaves & 40.1 & 25.9 & & 40.4 & 27.4 \\
Stems & 54.8 & 60.3 & & 59.6 & 71.3 \\
Inflorescences & 5.1 & 13.8 & & 0.0 & 1.3 \\
Chemical composition, \% of DM & & & & & \\
Ash & 7.7 & & & & \\
CP & 13.0 & 11.1 & & 19.2 & 17.6 \\
NDF & 47.7 & 55.1 & & 31.5 & 41.1 \\
Indigestible NDF (iNDF) & 5.2 & 8.2 & & 6.0 & 13.0 \\
Lignin & 2.8 & 3.5 & & 3.1 & 5.1 \\
NDS & 44.7 & 37.8 & & 56.7 & 48.4 \\
Water-soluble carbohydrates & 17.3 & 13.1 & & 9.6 & 8.0 \\
Cell wall characteristics, \% & & & & 19.1 & 31.8 \\
iNDF/NDF & 11.0 & 14.9 & & 9.9 & 12.4 \\
Lignin/NDF & 5.8 & 6.3 & & 52.1 & 38.9 \\
Lignin/iNDF & 53.0 & 42.0 & & & \\
\hline
\end{tabular}

${ }^{1}$ Neutral detergent solubles $=\mathrm{OM}-\mathrm{NDF}$.

effect of experimental diets on variation in rumen $\mathrm{pH}$ and ammonia $\mathrm{N}$ was assessed by using the following model for repeated measures:

$$
\begin{gathered}
\mathrm{Y}_{\mathrm{ijk}}=\mu+\mathrm{A}_{\mathrm{i}}+\mathrm{P}_{\mathrm{j}}+\mathrm{D}_{\mathrm{k}}+\mathrm{e}_{\mathrm{ijk}}+\mathrm{H}_{\mathrm{l}}+(\mathrm{AH})_{\mathrm{il}} \\
+(\mathrm{PH})_{\mathrm{jl}}+(\mathrm{PD})_{\mathrm{kl}}+\mathrm{e}_{\mathrm{ijk} \mathrm{k}},
\end{gathered}
$$

where $\mathrm{H}$ and $\mathrm{A}$ are fixed effect of time after morning feeding and animal, and all other variables are as defined previously. The analyses were performed using the Mixed procedure of SAS (Windows version 9.1.3, SAS Institute Inc., Cary, NC). Observations from one animal were missing from the mixed forage diet because of digestive disorders; therefore, the SEM of the mixture diet should be multiplied by 1.19 when making comparisons with the other mean values.

\section{RESULTS}

\section{Herbages and Silages}

Within the growth stages, red clover contained more stems and fewer inflorescences than grasses, resulting in a similar proportion of leaves (Table 1). Delaying the harvest was followed by changes in morphological and chemical composition, shown by an increased proportion of stems at the expense of leaves, lower concentrations of $\mathrm{CP}$ and NDS, and higher concentrations of NDF, iNDF, and lignin (Table 2).

The composition of silages reflected that of herbages except that WSC were fermented to lactic acid and VFA during ensiling (Table 2). Digestibility of OM was higher for grass than for red clover silages resulting in higher D-values for grass than for red clover silages. Delaying the harvest decreased ash and NDS concentrations in both plant species and increased the contents of NDF, iNDF, and lignin. The red clover silages contained less NDF but more iNDF and less pdNDF than grass silages. The ratio of lignin to NDF was higher in red clover silages than in grass silages.

\section{Intake}

The silage DM, total DM, and OM intakes were lowest for the early-cut red clover diet and highest when the mixed forage diet was fed (Table 3). Delaying the harvest tended to decrease DMI for grass and increase that for red clover $(P<0.10$ for plant species $\times$ growth stage interaction). Feeding the mixed forage diet, however, led to a higher $(P<0.05)$ DMI than feeding either of these silages as the sole forage in the diet.

The intake of NDF and pdNDF was lower $(P<$ $0.001)$, but the intake of iNDF was higher $(P<0.001)$ for red clover diets than for grass diets. The advancing growth stage increased $(P<0.01)$ intake of NDF and iNDF for both forages, but more markedly for red clover than for grass $(P<0.05$ for plant species $\times$ growth stage interaction).

There were no significant $(P>0.10)$ differences in milk yield between the treatments (Vanhatalo et al., 2009).

\section{Diurnal Variation in Rumen $\mathrm{pH}$ and Ammonia Concentration}

Treatment means for rumen fermentation data are presented in the companion paper (Vanhatalo et al., 
Table 2. Effects of dietary forage source and stage of maturity on chemical composition of silages

\begin{tabular}{lccccc}
\hline & \multicolumn{2}{c}{ Grass silage } & & \multicolumn{2}{c}{ Red clover silage } \\
\cline { 2 - 3 } \cline { 5 - 6 } Item & Early & Late & & Early & Late \\
\hline DM, \% & 24.9 & 25.7 & & 21.4 & 21.2 \\
Chemical composition, \% of DM & & & & & \\
Ash & 8.6 & 7.5 & & 10.2 & 9.3 \\
CP & 13.4 & 11.1 & & 21.2 & 18.1 \\
NDF & 50.0 & 57.0 & & 37.5 & 46.3 \\
Indigestible NDF (iNDF) & 5.7 & 8.4 & & 7.0 & 13.8 \\
Lignin & 2.2 & 2.9 & & 3.3 & 5.8 \\
NDS ${ }^{1}$ & 41.4 & 35.5 & & 52.3 & 44.4 \\
Lactic acid & 6.17 & 5.59 & & 5.01 & 3.82 \\
Formic acid & 1.21 & 1.35 & & 1.69 & 1.78 \\
Acetic acid & 2.29 & 1.98 & & 1.77 & 1.62 \\
Propionic acid & 0.013 & 0.011 & & 0.015 & 0.012 \\
Butyric acid & 0.034 & 0.014 & & 0.034 & 0.049 \\
Water-soluble carbohydrates & 6.13 & 3.07 & & 1.65 & 1.99 \\
pH & 4.04 & 3.97 & & 4.15 & 4.10 \\
Cell wall characteristics, \% & & & & 18.7 & 29.8 \\
iNDF/NDF & 11.4 & 14.7 & & 8.8 & 12.5 \\
Lignin/NDF & 4.4 & 5.1 & & 47.1 & 42.0 \\
Lignin/iNDF & 38.6 & 34.5 & & 75.8 & 67.2 \\
OMD, ${ }^{2} \%$ of OM & 77.7 & 72.9 & & 61.0 \\
D-value, ${ }^{3} \%$ of DM & 71.4 & 67.3 & & 104 \\
Silage DMI index & & & & & \\
\hline
\end{tabular}

${ }^{1}$ Neutral detergent solubles $=\mathrm{OM}-\mathrm{NDF}$.

${ }^{2}$ Digestibility of OM determined in vivo using sheep.

${ }^{3} \mathrm{D}$-value $=$ digestible $\mathrm{OM}$ in DM.

${ }^{4}$ According to Huhtanen et al. (2007).

2009). Diurnal changes in rumen $\mathrm{pH}$ and $\mathrm{NH}_{3}$ concentrations are presented in Figures 1 and 2. After the morning feeding, the lowest $\mathrm{pH}$ was found for the earlycut red clover silage diet as well as for the mixed forage diet (Figure 1) but there were no significant interactions $(P>0.10)$ of diet $\times$ time after morning feeding. During the feeding interval, the $\mathrm{NH}_{3}$ concentration remained at a higher level for red clover diets than for grass diets, with an intermediate level for the mixed forage diet (Figure 2). Delaying the harvest had no effect on the $\mathrm{NH}_{3}$ concentration for red clover silage diets but decreased the $\mathrm{NH}_{3}$ concentration for grass silage diets $(P<0.10$ for interaction of diet $\times$ time after morning feeding).

\section{Fiber Digestion and Passage Kinetics}

There were no significant differences in rumen pool sizes of DM and OM between plant species, but delaying the harvest increased $(P<0.01)$ them for both forages

Table 3. Effects of dietary forage source and stage of maturity on daily feed and nutrient intake of dairy cows

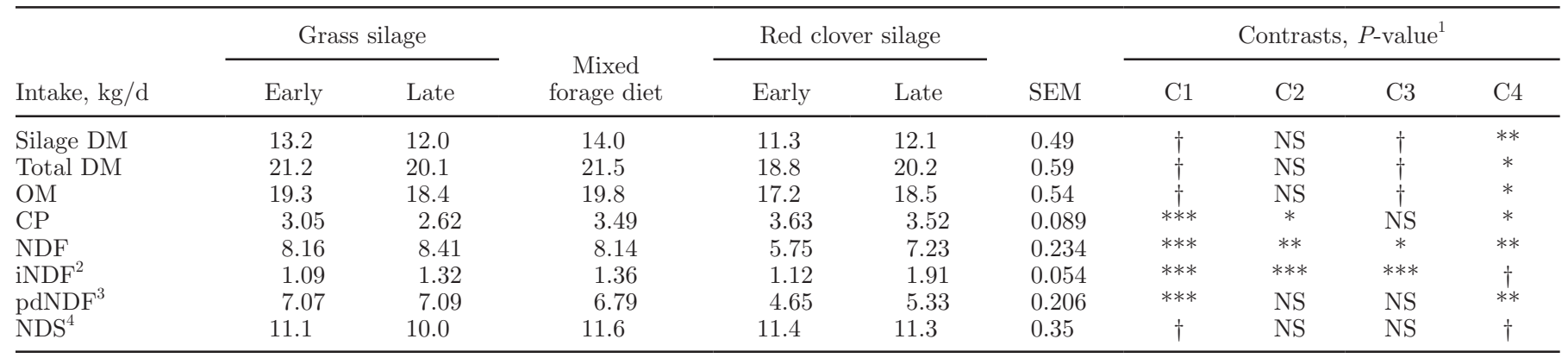

${ }^{1}$ Probability of the effects due to plant species (grass silage vs. red clover silage; C1), growth stage (early vs. late cut; C2), and their interaction (C3) and comparison between sole forages and a mixture (1:1) of late-cut grass silage and early-cut red clover silage (C4), respectively.

${ }^{2}$ Indigestible NDF.

${ }^{3}$ Potentially digestible NDF.

${ }^{4}$ Neutral detergent solubles $=\mathrm{OM}-\mathrm{NDF}$.

$\dagger P \leq 0.10 ;{ }^{*} P \leq 0.05 ; * * P \leq 0.01 ; * * P \leq 0.001 ; \mathrm{NS}=$ not significant $(P>0.10)$. 


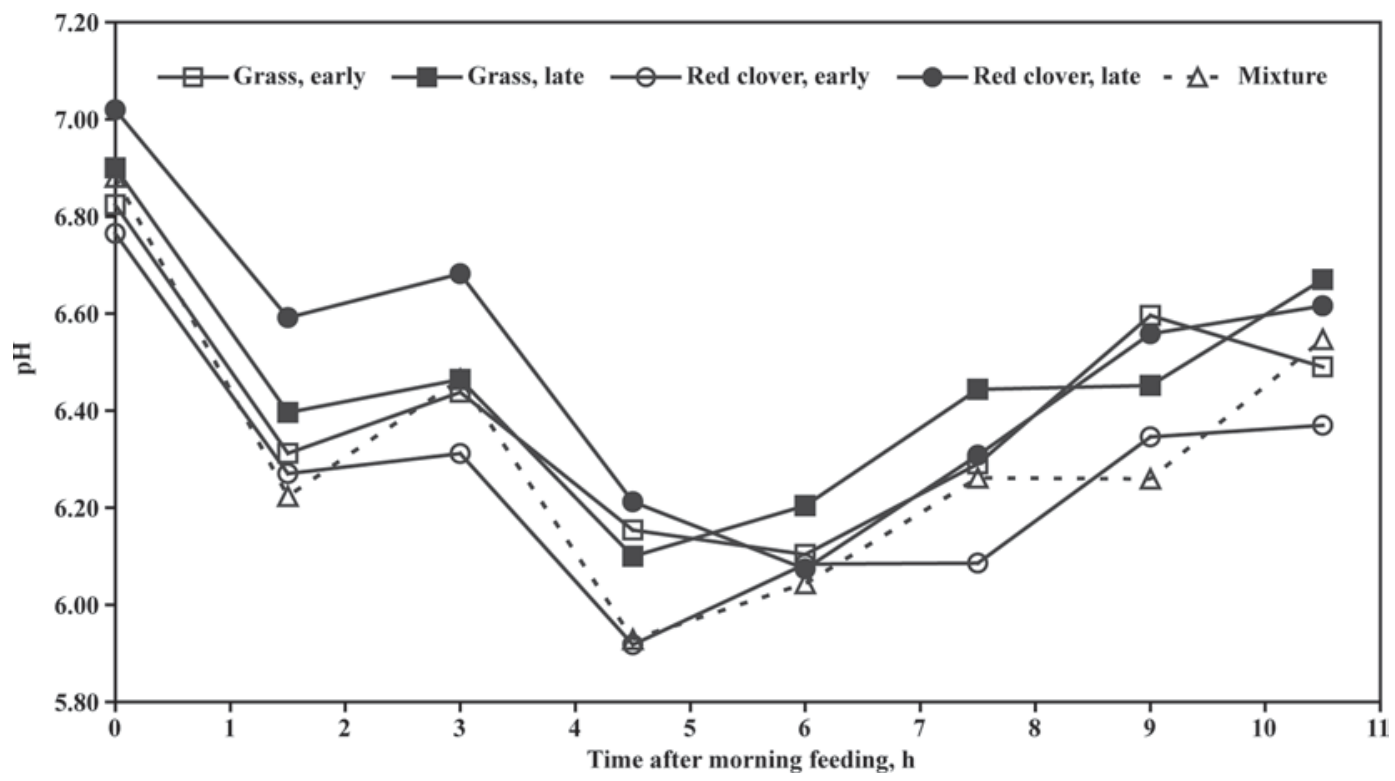

Figure 1. Effects of dietary forage source and stage of maturity on diurnal variations of rumen $\mathrm{pH}$.

(Table 4). Pool sizes of iNDF and the ratio of iNDF to pdNDF in the rumen contents were larger $(P<0.001)$ and pool sizes of NDF and pdNDF were smaller $(P<$ $0.01)$ for red clover than for grass silage diets. Delaying the harvest increased $(P<0.001)$ the pool size of iNDF for both species but more markedly for red clover than grass silage diets $(P<0.001$ for plant species $\times$ growth stage interaction).

Rumen outflow rate of DM and OM did not differ $(P>0.10)$ between plant species. Delaying the harvest tended to decrease DM outflow rate for grass but increased that for red clover silage diets (plant species $x$ growth stage interaction $P<0.10$ ). Outflow of iNDF and the ratio of iNDF to pdNDF in digesta entering the omasal canal were larger $(P<0.001)$ and the outflow of pdNDF was smaller $(P<0.001)$ for red clover than for grass silage diets. The digestion rate $\left(\mathrm{k}_{\mathrm{d}}\right)$ of pdNDF was faster $(P<0.01)$ for red clover diets than for grass silage diets. Delaying the harvest decreased $\mathrm{k}_{\mathrm{d}}$ for grass but increased it for red clover silage diets (plant species

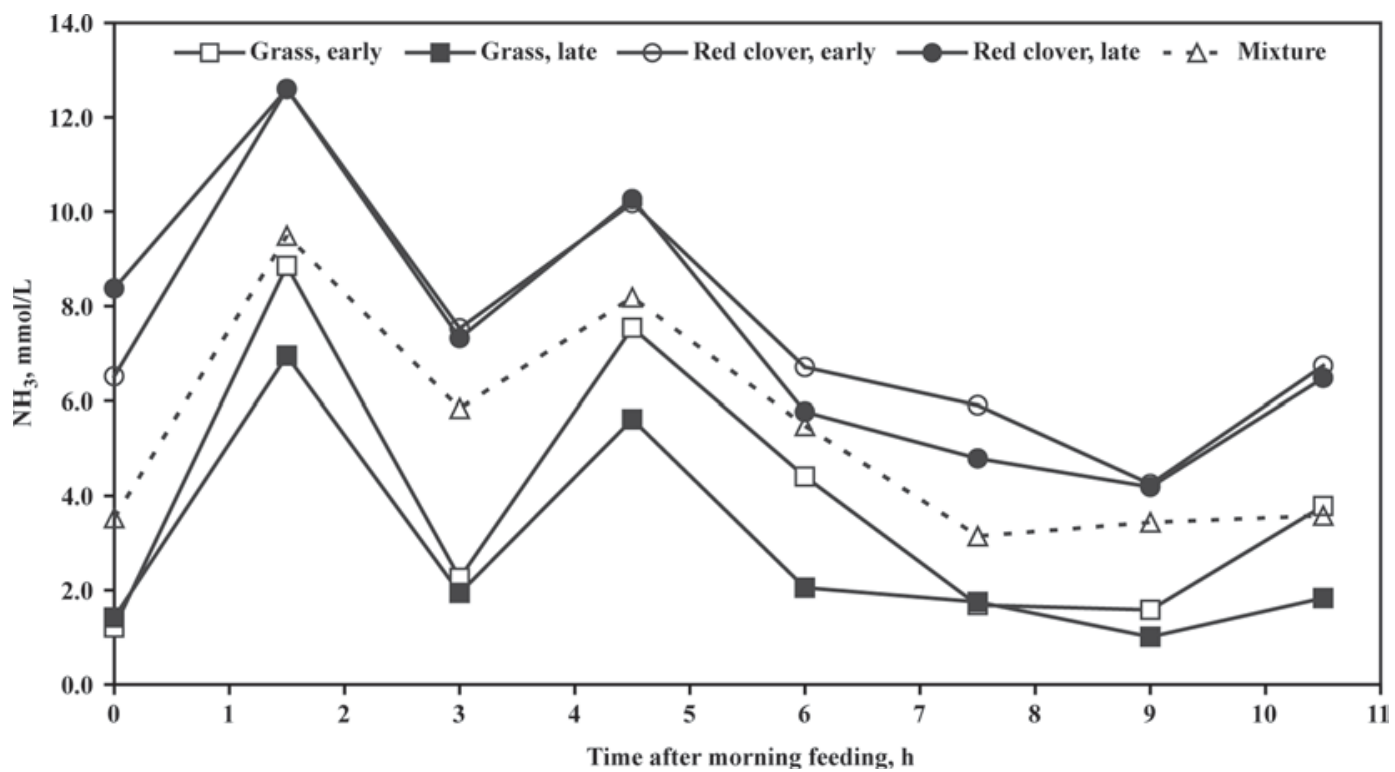

Figure 2. Effects of dietary forage source and stage of maturity on diurnal variations of rumen ammonia concentration. 
Table 4. Effects of dietary forage source and stage of maturity on average rumen pool size (kg), rumen outflow (kg/d), and rate of digestion $\left(\mathrm{k}_{\mathrm{d}}\right)$ of pdNDF and rate of passage $\left(\mathrm{k}_{\mathrm{p}}\right)$ from rumen of indigestible NDF (iNDF) of dairy cows

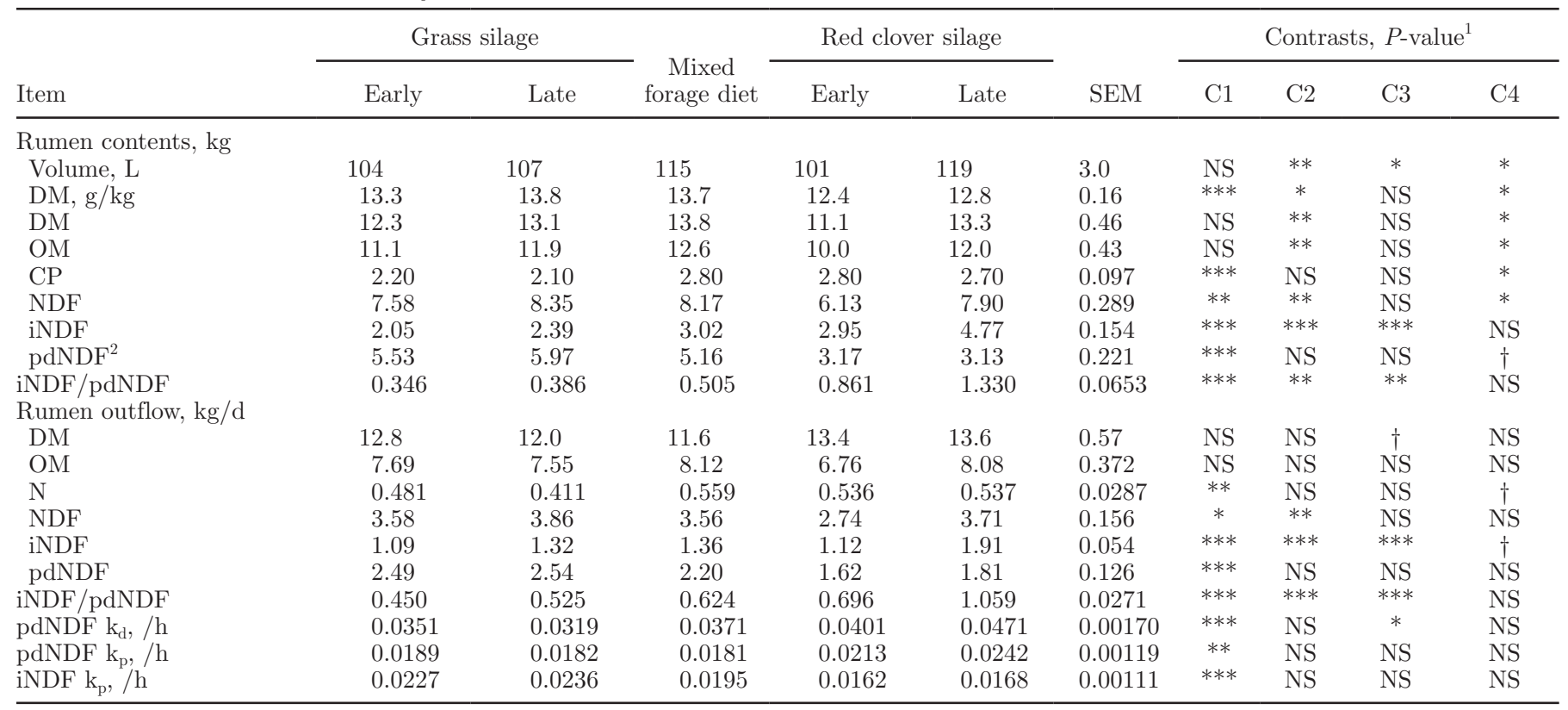

${ }^{1}$ Probability of the effects due to plant species (grass silage vs. red clover silage; C1), growth stage (early vs. late cut; C2), and their interaction (C3) and comparison between sole forages and a mixture (1:1) of late-cut grass silage and early-cut red clover silage (C4), respectively.

${ }^{2}$ Potentially digestible NDF.

$\dagger P \leq 0.10 ;{ }^{*} P \leq 0.05 ; * * P \leq 0.01 ; * * P \leq 0.001 ; \mathrm{NS}=$ not significant $(P>0.10)$.

$\times$ growth stage interaction $P<0.05)$. The passage rate $\left(\mathrm{k}_{\mathrm{p}}\right)$ of iNDF was lower $(P<0.001)$ for red clover diets than for grass silage diets.

Total-tract apparent digestibility of $\mathrm{OM}$ and $\mathrm{NDF}$ did not differ $(P>0.10)$ between plant species (Table $5)$ but was decreased $(P<0.01)$ by delaying the harvest. Digestibility of pdNDF was higher for red clover diets $(P<0.05)$.

\section{DISCUSSION}

\section{Herbage and Silage Composition}

All silages were restrictively fermented and of good fermentation quality as indicated by low $\mathrm{pH}$, low con- centration of fermentation acids, and a low proportion of ammonium $\mathrm{N}$ in total $\mathrm{N}$ of silages (see Vanhatalo et al., 2009). Despite the low DM concentration of grass and red clover herbages, the concentration of total fermentation acids in silages was moderate (between 5.5 and $8.5 \%$ of $\mathrm{DM}$ ), indicating restricted fermentation. The low concentration of WSC in red clover silages is most likely because of effluent losses during the ensiling period. The higher concentration of $\mathrm{CP}$ and the lower concentration of NDF in red clover compared with grass were consistent with earlier experiments (Bertilsson and Murphy, 2003; Dewhurst et al., 2003). Weisbjerg and Søegaard (2008) found that, at the same in vitro OM digestibility, the concentration of NDF was lower

Table 5. Effects of dietary forage source and stage of maturity on total-tract apparent digestibility of nutrients in dairy cows (\%)

\begin{tabular}{|c|c|c|c|c|c|c|c|c|c|c|}
\hline \multirow[b]{2}{*}{ Item } & \multicolumn{2}{|c|}{ Grass silage } & \multirow{2}{*}{$\begin{array}{c}\text { Mixed } \\
\text { forage diet }\end{array}$} & \multicolumn{2}{|c|}{ Red clover silage } & \multirow[b]{2}{*}{ SEM } & \multicolumn{4}{|c|}{ Contrasts, $P$-value ${ }^{1}$} \\
\hline & Early & Late & & Early & Late & & $\mathrm{C} 1$ & $\mathrm{C} 2$ & C3 & $\mathrm{C} 4$ \\
\hline OM & 75.0 & 71.9 & 73.8 & 76.2 & 72.3 & 0.61 & NS & $* * *$ & NS & NS \\
\hline $\mathrm{CP}$ & 68.1 & 66.8 & 68.9 & 73.2 & 70.3 & 0.58 & $* * *$ & $* *$ & NS & NS \\
\hline NDF & 62.1 & 58.0 & 60.9 & 60.2 & 54.7 & 1.44 & NS & $* *$ & NS & NS \\
\hline $\operatorname{pdNDF}^{2}$ & 70.5 & 68.0 & 72.6 & 74.0 & 72.8 & 1.53 & $*$ & NS & NS & NS \\
\hline $\mathrm{NDS}^{3}$ & 84.4 & 83.5 & 82.7 & 84.3 & 83.5 & 0.44 & NS & NS & NS & $*$ \\
\hline
\end{tabular}

${ }^{1}$ Probability of the effects due to plant species (grass silage vs. red clover silage; C1), growth stage (early vs. late cut; C2), and their interaction (C3) and comparison between sole forages and a mixture (1:1) of late-cut grass silage and early-cut red clover silage (C4), respectively.

${ }^{2}$ Potentially digestible NDF.

${ }^{3}$ Neutral detergent solubles $=\mathrm{OM}-\mathrm{NDF}$.

$\dagger P \leq 0.10 ;{ }^{*} P \leq 0.05 ;{ }^{*} P \leq 0.01 ;{ }^{* * *} P \leq 0.001 ; \mathrm{NS}=\operatorname{not}$ significant $(P>0.10)$. 
and the concentration of acid detergent lignin higher for legume herbages compared with grasses.

The lower concentration of NDF in red clover was associated with a higher concentration of iNDF compared with grass silages (on average 10.4 vs. $7.1 \%$ of DM for red clover and grass silages, respectively). The mean iNDF value of legume silages has been reported to be 13.2\% DM (Rinne et al., 2006) and that of grass silages 8.7\% DM (Nousiainen et al., 2004). Estimated by the proportion of the inflorescences, grasses in the present experiment seemed slightly more mature than red clover at both harvests. Early-cut red clover herbage was not flowering yet and the proportion of inflorescences was also low in the late cut. According to Frame et al. (1998, p. 205) flowering in red clover does not appear to have a direct depressive effect on digestibility as it has in grasses. In our case, using a Finnish genotype of red clover under boreal environmental conditions, the depression of digestibility with advancing growth was substantial although the proportion of flowers in late-cut red clover was rather low.

Changes measured in chemical composition because of the delay in harvest were typical of the effects of advancing growth stage, at least for grasses (Rinne et al., 2002; Kuoppala et al., 2008). The average daily rate of increase of NDF concentration was lower in red clover than in grass $(6.3$ vs. $7.8 \mathrm{~g} / \mathrm{d}$ for red clover and grass, respectively), whereas the opposite was true with iNDF (4.9 vs. $3.0 \mathrm{~g} / \mathrm{d})$. The average daily decrease of the D-value was 4.9 versus $4.6 \mathrm{~g} / \mathrm{d}$ for red clover and grass, respectively. The value for red clover was higher than those observed earlier $(2.6 \mathrm{~g} / \mathrm{d}$ according to Rinne and Nykänen, 2000; and $3.6 \mathrm{~g} / \mathrm{d}$ in the data of Vanhatalo et al., 2008) whereas the rate in D-value decline of grasses was typical (range of 4.8 to $5.6 \mathrm{~g} / \mathrm{d}$; Rinne and Nykänen, 2000; Rinne et al., 2002; Kuoppala et al., 2008; Vanhatalo et al., 2008). Unpublished observations from our laboratory have shown relatively curvilinear D-value development of red clover so that the $\mathrm{D}$-value is maintained at a relatively high level for a long period and then starts to decrease steeply, whereas the D-value decline of grasses is more linear. These types of differences between the species make the comparisons between them very sensitive to the choice of harvest times when only 2 cuts are taken. This may also explain the lack of differences in daily D-value decline, which is typically observed between red clover and grasses.

\section{Intake}

The highest silage DMI was found for cows consuming the mixed forage diet in accordance with previous experiments (Bertilsson and Murphy, 2003; Dewhurst et al., 2003). Tuori et al. (2002) reported that increasing the proportion of red clover from 0 to $67 \%$ in the mixed red clover grass silage increased the DMI, but the lowest DMI was measured when red clover silage was fed as the sole forage. Mixing early-cut red clover silage with late-cut grass silage of lower digestibility caused a daily DMI increase of 2.7 or $2.0 \mathrm{~kg}$ compared with early-cut red clover or with late-cut grass silage, respectively. Mixing these 2 very different silages seemed to induce positive associative effects for intake. One effect was an increased $\mathrm{NH}_{3}$ concentration in the rumen for the mixed forage diet compared with the late-cut grass silage diet (Vanhatalo et al., 2009), which may enhance microbial fermentation.

In the data analysis of Huhtanen et al. (2007), factors affecting silage DMI were evaluated and the relative silage DMI index was developed. The index predicts higher intakes of silages containing legumes compared with pure grass silages. Because of the high level of formic acid additive used in the present study, fermentation characteristics of the red clover and grass silages irrespective of the growth stage were similar. A high Dvalue and low concentration of total fermentation acids generated the highest silage DMI index for early-cut red clover silage, indicating that the factors depending on the feed itself should have promoted high DMI. The reason for the unexpectedly low DMI of highly digestible early-cut red clover silage may be attributable to metabolic factors regulating feed DMI, because physical constraints could not be major restricting factors as indicated by the smallest rumen pool size of DM and NDF. However, milk yield of cows consuming early-cut red clover silage was not affected, as reported in the companion paper (Vanhatalo et al., 2009). These findings suggest either that early-cut red clover satisfied the nutrient requirements for the milk yield potential of current cow population, or that the nutrient composition was not optimal to reach higher production and DMI. The concentrations of VFA and $\mathrm{NH}_{3}$ in the rumen were highest on this diet despite the lowest DMI (Vanhatalo et al., 2009). According to Choung et al. (1990) the intake of high-protein silages may be depressed by factors associated with high rates of absorption of $\mathrm{NH}_{3}$ from the rumen. However, the level of even the highest $\mathrm{NH}_{3}$ concentration peak during the feeding interval (Figure 2) for the early-cut red clover silage diet was lower than the values of Choung et al. (1990), which reduced DMI.

Delaying the harvest decreased silage DMI of grass silage diets as documented in several experiments (Huhtanen et al., 2007). However, the opposite was found for red clover silage diets. The delay of $14 \mathrm{~d}$ in the harvest of red clover induced an average increase of $0.8 \mathrm{~kg}$ in daily DMI in spite of the decreased digestibility. These 
results agree with Vanhatalo et al. (2008), who found an increase of $1 \mathrm{~kg}$ in daily DMI when more mature red clover silage was fed. These 2 silages were harvested in the regrowth with 2 wk difference in growing time. In contrast, a 2-wk delay in the harvest of primary growth red clover silages resulted in a decrease of 1.7 $\mathrm{kg}$ in daily DMI in the same experiment (Vanhatalo et al., 2008). Also, Hoffman et al. (1997), who compared red clover with alfalfa silages, both cut at 2 stages of growth in primary growth, found that delaying the harvest decreased silage DMI of both plant species. Results from dairy cows consuming red clover silage cut at different growth stages are rare, and the effects of maturity may have been confounded with harvesting season. Furthermore, in an experiment with lambs eating regrowth red clover silage, Fraser et al. (2000) found that delaying the harvest did not affect voluntary intake. In general, increasing the maturity of the red clover ensiled did not seem to affect silage DMI as consistently as it did that of grasses. According to Dewhurst et al. (2003), the superiority of legume silages was associated with high silage DMI despite lower DM digestibility of diet compared with grass silage diets. In summary, the effect of maturity of red clover on silage DMI cannot be explained by changes in digestibility; some other factors are also involved and more research is needed to elucidate them.

\section{Diurnal Changes in Rumen Fermentation}

Rumen $\mathrm{pH}$ remained above 6.0 for most of the time during the feeding interval irrespective of the plant species or forage maturity stage (Figure 1). Depression of $\mathrm{pH}$ to just below 6.0 was suggested to result in a small decrease in fiber digestion by Hoover (1986). The ruminal concentration of $\mathrm{NH}_{3}$ reflected the difference in $\mathrm{N}$ content of silages, with higher $\mathrm{N}$ content of red clover silages resulting in a higher $\mathrm{NH}_{3}$ concentration. Furthermore, $\mathrm{NH}_{3}$ concentration remained higher for red clover silage diets during the feeding interval (Figure 2) with a peak value of $12.6 \mathrm{mmol} / \mathrm{L}$. For grass silage diets, average $\mathrm{NH}_{3}$ concentration, as well as the concentration during most of the feeding interval, was lower than for red clover silage diets and $<5.7 \mathrm{mmol} / \mathrm{L}$ ( $8 \mathrm{mg}$ per $100 \mathrm{~mL}$ ), which was suggested by Hoover (1986) as a critical value for fiber digestion.

\section{Fiber Digestion and Passage Kinetics}

Rumen pool sizes of NDF and pdNDF in the present study were smaller for red clover silage diets than for grass silage diets in accordance with Dewhurst et al. (2003). The pool sizes of iNDF for both red clover diets were larger than for the late-cut grass diet. The larger pool size of iNDF was because of the slower iNDF outflow rate of red clover. It seemed that iNDF accumulated into the rumen with red clover diets, but it is difficult to draw any conclusion about cause and effect: is the accumulation of iNDF due to plant characteristics or is it because rumen fill is less limiting with red clover diets? The higher digestion rate of pdNDF for red clover diets resulted in a smaller pool size of pdNDF and NDF compared with grass silage diets.

The ratio of iNDF to pdNDF was higher in rumen contents than in digesta entering the omasal canal for red clover silage diets, whereas the opposite was true for grass silage diets. Lower iNDF to pdNDF ratio in the rumen relative to those particles entering the omasal canal would indicate selective retention of highly digestible particles, whereas a higher ratio in the rumen is difficult to explain without consideration of 2 types of forage particles with different passage rates.

Selective retention means that large particles and particles containing a high proportion of digestible material are selectively retained in the rumen, whereas the particles containing less digestible material have a higher probability of escaping (Huhtanen et al., 2006a). In terms of passage kinetics this means that the rate of particulate matter passage increases as a function of time and leads to a situation in which particles leaving the rumen have a higher iNDF concentration relative to those particles present in the rumen. Selective passage increases the pool size of pdNDF relative to iNDF and leads to a situation in which the pdNDF passage rate appears to be lower than that of iNDF, even when all particles leaving the rumen have an identical passage rate; that is, particles comprise a single homogeneous pool with respect to passage kinetics.

Despite the higher concentration of lignin and iNDF in red clover fiber, a higher $k_{d}$ was observed for red clover silage diets compared with grass silage diets. Legumes can have a much higher lignin content than grasses and at the same time have a higher rate of cell wall digestion. This apparent contradiction can be explained by the fact that the high lignin content is all located in the xylem where the concentration is such that the walls are completely indigestible, whereas other tissues are almost completely digestible (Wilson and Kennedy, 1996). In grasses, the lignin content is lower but distributed throughout all tissues except phloem. Lower concentrations of indigestible material can therefore protect a larger amount of cell wall from digestion in grasses. Huhtanen et al. (2006b) found an empirical relationship between iNDF concentration $(\mathrm{kg} / \mathrm{kg}$ of $\mathrm{DM})$ and in vivo $\mathrm{OM}$ digestibility $(\mathrm{kg} / \mathrm{kg}$ of $\mathrm{OM})$ with a slope of -1.51 and -1.15 for primary growth grass silages and legume silages, respectively. In spite of the higher content of indigestible material, legumes were 
digested at a higher rate compared with grasses (Smith et al., 1972; Wilson and Kennedy, 1996; Weisbjerg and Søegaard, 2008). Further, Rinne and Nykänen (2000) reported that the difference in digestion rate between red clover and timothy was much higher for stems than for leaves.

Dewhurst et al. (2003) suggested that red clover silage and a mixture of red clover and grass silages behaved similarly to grass silage compared with white clover and alfalfa silages. They speculated that for these diets the digestion kinetics were influenced by thicker mats, which caused greater entrapment of feed particles, longer retention times, lower passage rates, and greater fiber digestibility. Our results showed obvious differences between red clover and grass with respect to digestion and passage kinetics. Dewhurst et al. (2003) used a proportional mixture of all 3 cuts of the year, whereas our silages were all harvested from the primary growth. This may partly explain the discrepancies between the results. At least for grasses, the harvesting season may affect the digestion properties (Kuoppala et al., 2004).

Delaying the harvest decreased $k_{d}$ of pdNDF for grass but increased that for red clover in the present study. However, maturing has been shown to decrease the digestion rate for both legumes and grasses (Buxton, 1989; Rinne and Nykänen, 2000) but the change was slower for red clover than for grasses. Hoffman et al. (1997) found a faster in vitro NDF digestion rate for later harvested legumes for the first year, but not for the second year. The relationship between maturity and digestion and passage kinetics does not seem to be clear. According to Huhtanen et al. (2006a), the passage kinetics often reflect the effects of feed intake, which may be the case in the present study in which the DMI was increased by delaying the harvest for red clover.

Rinne and Nykänen (2000) reported that the digestion rate for the leaves of red clover and grass (timothy) was almost the same, whereas for stems it was clearly higher for red clover than for timothy. The increasing proportion of stems with advancing maturity appeared not to affect the digestion rate for red clover as negatively as it did for grasses.

\section{CONCLUSIONS}

Observed differences in fiber characteristics of red clover and grass silages were reflected in ruminal digestion and passage kinetics of these forages. Indigestible NDF accumulated in the rumen of cows fed red clover silage diets, whereas accumulation of pdNDF was observed for cows fed grass silage diets. Accumulation of pdNDF is a clear indication of selective retention of previously ingested feed particles in the rumen, but
iNDF accumulation tends to suggest 2 types of feed particles, with a faster passage rate for particles enriched with pdNDF and a slower rate for particles with a high concentration of iNDF. Regardless of the higher passage rate for red clover pdNDF, the higher digestion rate of red clover pdNDF relative to grass silage diets resulted in higher total-tract pdNDF digestibility for red clover silage diets. Similar total-tract NDF digestibility in combination with a higher concentration of cell solubles for red clover diets resulted in similar total-tract OM digestibility of these diets.

The highest silage intake was observed for a mixture of red clover and grass silages. The low intake of earlycut red clover silage could not be attributed to silage D-value, fermentation characteristics, or rumen fill, but was most likely related to nutritionally suboptimal composition because inclusion of moderate quality grass silage improved silage intake. The effects of increasing red clover maturity appear less predictable than those of grass silages.

\section{ACKNOWLEDGMENTS}

The authors thank staff of experimental unit led by Laila Hakkarainen for care of experimental animals, and laboratory staff led by Vesa Toivonen for chemical analyses of the samples, both at MTT Agrifood Research Finland in Jokioinen. This work was financially supported by the Finnish Ministry of Agriculture and Forestry and Agricultural Foundation of August Johannes and Aino Tiura.

\section{REFERENCES}

Bertilsson, J., and M. Murphy. 2003. Effects of feeding clover silages on feed intake, milk production and digestion in dairy cows. Grass Forage Sci. 58:309-322.

Buxton, D. R. 1989. In vitro digestion kinetics of temperate perennial forage legume and grass stems. Crop Sci. 29:213-219.

Choung, J. J., D. G. Chamberlain, P. C. Thomas, and I. Bradbury. 1990. The effects of intraruminal infusions of urea on the voluntary intake and milk production of cows receiving grass silage diets. J. Dairy Res. 57:455-464.

Dewhurst, R. J., R. T. Evans, N. D. Scollan, J. M. Moorby, R. J. Merry, and R. J. Wilkins. 2003. Comparison of grass and legume silages for milk production. 2. In vivo and in sacco evaluations of rumen function. J. Dairy Sci. 86:2612-2621.

Frame, J., J. F. L. Charlton, and A. S. Laidlaw. 1998. Temperate Forage Legumes. CAB International, Wallingford, UK.

Fraser, M. D., R. Fychan, and R. Jones. 2000. Voluntary intake, digestibility and nitrogen utilization by sheep fed ensiled forage legumes. Grass Forage Sci. 55:271-279.

Heikkilä, T., V. Toivonen, and T. Mela. 1992. Comparison of red clover-grass silage with grass silage for milk production. Pages 388-391 in Proc. 14th Gen. Mtg. Eur. Grassl. Fed., Lahti, Finland. European Grassland Federation, Lahti, Finland.

Heikkilä, T., V. Toivonen, and T. Mela. 1996. Effects of red clover-grass, grass and annual ryegrass silages with two concentrate protein levels on milk production. Grassland and Land Use Systems. Pages 447-450 in Proc. 16th General Mtg. Eur. Grassl. Fed., Grado (Gorizia), Italy. G. Parente, J. Frame and S. Orsi, ed. ERSA, Ente 
Regionale per la Promozione e lo Sviluppo dell'Agricolture Via Montesanto, Italy.

Hoffman, P. C., D. K. Combs, N. M. Brehm, and D. A. Welch. 1997. Performance of lactating dairy cows fed red clover or alfalfa silage. J. Dairy Sci. 80:3308-3315.

Hoover, W. H. 1986. Chemical factors involved in ruminal fiber digestion. J. Dairy Sci. 69:2755-2766.

Huhtanen, P., S. Ahvenjärvi, M. Weisbjerg, and P. Nørgaard. 2006a. Digestion and passage of fibre in ruminants. Pages $87-135$ in Ruminant Physiology: Digestion, Metabolism and Impact of Nutrition in Gene Expression, Immunology and Stress. K. Sejrsen, T. Hvelplund, and M. O. Nielsen, ed. Wageningen Academic Publishers, Wageningen, the Netherlands.

Huhtanen, P., K. Kaustell, and S. Jaakkola. 1994. The use of internal markers to predict total digestibility and duodenal flow of nutrients in cattle given six different diets. Anim. Feed Sci. Technol. 48:211-227.

Huhtanen, P., J. Nousiainen, and M. Rinne. 2006b. Recent developments in forage evaluation with special reference to practical applications. Agric. Food Sci. 15:293-323.

Huhtanen, P., M. Rinne, and J. Nousiainen. 2007. Evaluation of the factors affecting silage intake of dairy cows: A revision of the relative silage dry-matter intake index. Animal 1:758-770.

Kuoppala, K., M. Rinne, S. Ahvenjärvi, J. Nousiainen, and P. Huhtanen. 2004. Digestion kinetics of NDF in dairy cows fed silages from primary growth and regrowth of grass. J. Anim. Feed Sci. 13(Suppl. 1):127-130.

Kuoppala, K., M. Rinne, J. Nousiainen, and P. Huhtanen. 2008. The effect of cutting time of grass silage in primary growth and regrowth and the interactions between silage quality and concentrate level on milk production of dairy cows. Livest. Sci. 116:171-182.

Mertens, D. R. 1993. Kinetics of cell wall digestion and passage in ruminants. Pages 535-570 in Forage Cell Wall Structure and Digestibility. H. G. Jung, D. R. Buxton, R. Buxton, R. D. Hatfield, and J. Ralph, ed. American Society of Agronomy Inc., Crop Science Society of America Inc., Soil Science Society of America Inc., Madison, WI.

Nousiainen, J., S. Ahvenjärvi, M. Rinne, M. Hellämäki, and P. Huhtanen. 2004. Prediction of indigestible cell wall fraction of grass silage by near infrared reflectance spectroscopy. Anim. Feed Sci. Technol. 115:295-311.

Rinne, M., P. Huhtanen, and S. Jaakkola. 2002. Digestive processes of dairy cows fed silages harvested at four stages of grass maturity. J. Anim. Sci. 80:1986-1998.

Rinne, M., and A. Nykänen. 2000. Timing of primary growth harvest affects the yield and nutritive value of timothy-red clover mixtures. Agric. Food Sci. Finl. 9:121-134.
Rinne, M., A. Olt, J. Nousiainen, A. Seppälä, M. Tuori, C. Paul, M. D. Fraser, and P. Huhtanen. 2006. Prediction of legume silage digestibility from various laboratory methods. Grass Forage Sci. 61:354-362.

Robertson, J. B., and P. J. Van Soest. 1981. The detergent system of analysis and its application to human foods. Pages $123-158$ in The Analyses of Dietary Fiber in Foods. W. D. T. James, and O. Theander, ed. Marcel Dekker, New York, NY.

Smith, L. W., H. K. Goering, and C. H. Gordon. 1972. Relationships of forage compositions with rates of cell wall digestion and indigestibility of cell walls. J. Dairy Sci. 55:1140-1147.

Tuori, M., L. Syrjälä-Qvist, and S. Jansson. 2002. Red clover and meadow fescue silages fed in different proportions in milk production. Pages 130-131 in Proc. XIIIth Int. Silage Conf., Auchincruive, Scotland. L. Gechie, and C. Thomas, ed. Scottish Agricultural College, Auchincruive, Scotland.

Van Soest, P. J. 1994. Nutritional Ecology of the Ruminant. 2nd ed. Comstock Publishing Associates, Cornell University Press, Ithaca, NY.

Van Soest, P. J., J. B. Robertson, and B. A. Lewis. 1991. Methods for dietary fibre, neutral detergent fibre and nonstarch polysaccharides in relation to animal nutrition. J. Dairy Sci. 74:3583-3597.

Vanhatalo, A., K. Kuoppala, S. Ahvenjärvi, and M. Rinne. 2009 Effects of feeding grass or red clover silage cut at two maturity stages in dairy cows. 1. Nitrogen metabolism and supply of amino acids. J. Dairy Sci. 92:5620-5633.

Vanhatalo, A., P. Pursiainen, K. Kuoppala, M. Rinne, and M. Tuori. 2008. Effects of harvest time of red clover silage on milk production and composition. Biodiversity and Animal Feed. Future Challenges for Grassland Production. Pages 391-393 in Proc. 22nd Gen. Mtg. Eur. Grassl. Fed., Uppsala, Sweden. A. Hopkins, T. Gustafsson, J. Bertilsson, G. Dalin, N. Nilsdotter-Linde, and E. Spörndly, ed. Swedish University of Agricultural Sciences (SLU), Uppsala.

Weisbjerg, M. R., and K. Søegaard. 2008. Feeding value of legumes and grasses at different harvest times. Biodiversity and Animal Feed. Future Challenges for Grassland Production. Pages 513-515 in Proc. 22nd Gen. Mtg. Eur. Grassl. Fed., Uppsala, Sweden. A. Hopkins, T. Gustafsson, J. Bertilsson, G. Dalin, N. NilsdotterLinde, and E. Spörndly, ed. Swedish University of Agricultural Sciences (SLU), Uppsala.

Wilson. J. R., and P. M. Kennedy. 1996. Plant and animal constraints to voluntary feed intake associated with fibre characteristics and particle breakdown and passage in ruminants. Aust. J. Agric. Res. $47: 199-225$. 